\title{
Risk factors for trypanosomiasis by Trypanosoma vivax in cattle raised in Rio Grande do Norte state
}

\author{
Fatores de risco para tripanossomose por Trypanosoma vivax em bovinos \\ criados no estado do Rio Grande do Norte

\begin{abstract}
Jael Soares Batista ${ }^{\text {* }}$, Gabriela Hémylin Ferreira Moura', Francisco Canindé Lopes ${ }^{1}$, Kaliane Alessandra Rodrigues de Paiva', Hélio Noberto de Araújo Júnior ${ }^{1}$, Rayr Cezar de Souza Góis',
\end{abstract} \\ Kizzy Millenn de Freitas Mendonça Costa', Wesley Adson Costa Coelho', Carlos Iberê Alves Freitas'
}

\begin{abstract}
The objective of this study was to determine the prevalence of anti Trypanosoma vivax antibodies and the possible risk factors associated with the infection in cattle in Rio Grande do Norte, Northeastern Brazil, through a cross-sectional epidemiological study, with non-probabilistic convenience sampling. A total of 467 cattle's serum samples were analyzed by indirect immunofluorescence. Forty-two samples tested positive for Trypanosoma vivax IgG antibodies, corresponding to the prevalence of $9 \%$. Risk factors influencing the occurrence of trypanosomiasis were milk exploration, raising of European breeds, productivity category: lactation cow, purchase of new cattle, foraging habits near ponds and rivers, and the presence of mechanical vectors. So, high prevalence in beef animals (59.5\%), females $(95.2 \%)$, European breed $(88.1 \%)$, lactating cows $(85.7 \%)$, pasture at banks of dams and rivers $(95.2 \%)$, in addition to the presence of mechanical vectors $(81 \%)$ and acquisition of animals $(88.1 \%)$, indicates the expansion of trypanosomiasis in Northeastern semi-arid region, and the information obtained may explain the epidemiological factors that determine the occurrence of trypanosomiasis by T. vivax in this region.
\end{abstract}

KEYWORDS: epidemiology; risk factors; northeast Brazil; serum prevalence; trypanosomosis.
RESUMO: Objetivando determinar a prevalência de anticorpos anti-Trypanosoma vivax e os possíveis fatores de risco associados à infecção em bovinos no estado do Rio Grande do Norte, nordeste do Brasil, o trabalho consistiu em um estudo epidemiológico transversal, com amostragem não probabilística por conveniência, no qual foram analisadas, por meio da reaçáo de imunofluorescência indireta, 467 amostras de soro sanguíneo de bovinos. Das amostras testadas, 42 foram reagentes para anticorpos IgG anti-Trypanosoma vivax, o que correspondeu à prevalência de $9,0 \%$. Os fatores de risco que influenciaram a ocorrência da tripanossomose foram: exploração com finalidade do tipo leite, criação de bovinos de raça europeia, categoria animal vaca em lactaçáo, aquisiçáo de animais, forrageamento das margens de açudes e rios, além da presença de vetores mecânicos. A alta prevalência encontrada em animais de corte (59,5\%), fêmeas $(95,2 \%)$, raça europeia $(88,1 \%)$, vacas em lactação $(85,7 \%)$, pastagem a margens de açudes e rios $(95,2 \%)$, além da presença de vetores mecânicos $(81 \%)$ e aquisição de animais $(88,1 \%)$, indica a expansão da tripanossomose no semiárido do Nordeste, e as informaçôes obtidas poderão esclarecer os fatores epidemiológicos que determinam a ocorrência da tripanossomose por T. vivax na região.

PALAVRAS-CHAVE: epidemiologia; fatores de risco; nordeste do Brasil; soro prevalência; tripanossomose. 


\section{INTRODUCTION}

Trypanosoma vivax is a pathogenic hemoparasite that has a negative impact on the health and productivity of domestic ruminants in African countries, especially in regions occupied by the biological vector, the tsetse fly (ADAMS et al., 2010; BITTAR et al., 2015). Adaptation by mechanical transmission through hematophagous dipterans such as Stomoxys spp. and Tabanus $s p p$., associated to the displacement of animals from endemic to non-endemic regions, has contributed to the expansion of T. vivax to other regions of the world, such as South America, Central America and the Caribbean (SILVA et al., 2002).

Trypanosomiasis by T. vivax presents different epidemiological situations in several regions of Brazil. The Northern region and the Mato Grosso Pantanal can be considered as enzootic stability for trypanosomiasis (GUERRA et al., 2013). Due to the abundance of mechanical vectors, most of the year, the animals develop active immunity. Therefore, the disease becomes benign, infected animals are asymptomatic, and morbidity and mortality decrease significantly (DESQUESNES, 2004).

In non-endemic regions, such as the semi-arid Northeast of Brazil, as a consequence of prolonged periods of drought and high temperatures, it becomes an unfavorable environment for the development of vectors, causing non-exposure of the animals and, therefore, do not develop active immunity. However, outbreaks occur more frequently during the rainy season, when there is the increase in the vector population (BATISTA et al., 2011; RODRIGUES et al., 2013).

In recent studies that reported outbreaks of T. vivax infection in the Brazilian semi-arid region, the parasite showed high pathogenicity. The disease was characterized by high morbidity and mortality, decrease in milk production, perinatal mortality and reproductive disorders characterized by abortion, recurrence of birth, birth of stillborn infants, weak offspring and temporary or permanent anestrous (BATISTA et al., 2008).

Despite frequent reports on the occurrence of trypanosomiasis outbreaks in Brazil, factors related to host, environment and animal management, which favor the occurrence and severity of the infection, are still little known. Thus, the present work was structured aiming to determine the prevalence of trypanosomosis by T. vivax.

\section{MATERIALS AND METHODS}

The Mossoró microregion belongs to the West Potiguar mesorregion of the state of Rio Grande do Norte, divided into six cities: Areia Branca, Barauna, Serra do Mel, Mossoró, Tibau and Grossos. The climate of the study area is of the semi-arid hot tropical type, falling into the Köppen-Geiger climate classification as semi-arid climate or steppe climate $(\mathrm{BSw} \mathrm{H})$, with the annual average temperature of $27^{\circ} \mathrm{C}$, relative humidity of $50 \%$ and annual average rainfall of $500 \mathrm{~mm}$, with two defined seasons in the year: a rainy one from three to five months, denominated regionally of winter (February to May) and a long dry season, called summer, that lasts from seven to nine months (June to January) (CARMO FILHO et al., 1987).

Agriculture is the main economic activity of these cities, with emphasis on cattle, goats and sheep, managed in an extensive breeding system, in native pastures. Due to this context, the research has epidemiological and cross-sectional character, with non-probabilistic sampling for convenience. Sample size was calculated according to THRUSFIELD (2004) recommendations. The number of animals in the cities studied was 30,922 (IBGE, 2012), considering an unknown prevalence, estimated at $50 \%$, with $95 \%$ confidence level and a statistical error of $5 \%$, so a minimum total sample was determined of 384 animals. Thus, 467 animals were surveyed, distributed in 18 properties (Fig. 1).

For the survey of the risk factors, the following variables were considered as possible risk factors: the purpose of the exploration (milk or cut), sex, race - animal (lactating cow, dry cows, steers, calves) - , foraging of the banks of dams and rivers (yes or no), presence of vector insects (yes or no), acquisition of animals (yes or no), and shared use of syringes and needles (yes or no).

Blood collection was performed from July to September 2013 and January to May 2014 by means of external jugular

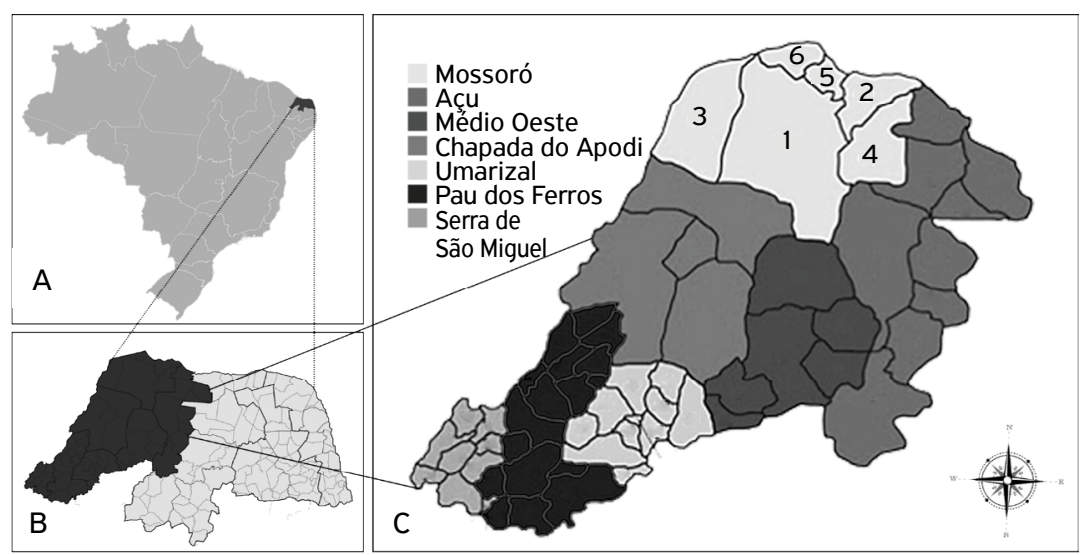

Figure 1. Map of Brazil highlighting the state of Rio Grande do Norte and enlargement of the cities where 467 animals were surveyed, distributed in 18 properties. 
vein puncture using $5 \mathrm{~mL}$ disposable syringes containing 5,000 IU.mL $\mathrm{mL}^{-1}$ sodium heparin as anticoagulant, with posterior obtaining the serum and storage at $-20^{\circ} \mathrm{C}$ until the serology was performed. The sera were serially diluted in the proportions of $1: 10$, $1: 20,1: 40,1: 80,1: 160,1: 320,1: 640,1: 1,280$ in 0.15 phosphate buffered saline ( $\mathrm{pH} 7.2)$ two times as a reaction screen, and tested for anti-Trypanosoma vivax $\operatorname{IgG}$ antibodies using fluorescein isothiocyanate-labeled anti-bovine fluorescent conjugate (Sigma, St. Louis, MO, USA), as described by the method of SILVA et al. (2002).

The positive samples were further diluted until the fluorescence was observed. Titers with fluorescence $\geq 1: 80$ were considered positive, since, in this proportion, more than half of the observed field presents trypanosomes fluorescing, according to the standardization of the conjugate. Bovine sera infected with T. vivax as a positive control and as negative $0.15 \mathrm{M}$ phosphate buffered saline ( $\mathrm{pH}$ 7.2) were applied to each slide.

The data were entered in spreadsheet and transferred to the statistical software Statistical Package for the Social Sciences (SPSS) 21.0, and later codified for analysis. The associations of the variables with the seropositivity to T. vivax were determined using the chisquare test $\left(\chi^{2}\right)$ and Fisher's exact test. The latter was used when the values presented an expected frequency of less than 5 . Odds ratio $(\mathrm{OR})$ and $95 \%$ confidence intervals $(\mathrm{CI})$ were also obtained.

A logistic regression model was developed to study simultaneously, including factors that may be involved in the prevalence of T. vivax infection in cattle. The analysis was composed of variables that had a value of $\mathrm{p}<0.20$ and some that did not present significant differences, but which were considered important as associated factors for infection. Logistic models were excluded, as well as those ones with high amplitude confidence intervals in the odds ratio estimates and the ones with collinearities. Thus, the analysis was composed for the final model, variables with significance level of $\mathrm{p}<0.10$, which were again evaluated by the complete method of successive removal of the variables. At this stage, the significance level of $\mathrm{p}<0.05$ was used. As a measure of logistic regression fit, the Hosmer-Lemeshow test was used, in which $\mathrm{p} \geq 0.05$ indicates that the model is adjusted.

This study was carried out under the approval of the Ethical Committee on the Use of Animals (CEUA) of the Universidade Federal Rural do Semi-Árido (UFERSA), under Opinion no. 41/2011, respecting all the ethical precepts of animal protection.

\section{RESULTS}

Among the 467 animals examined, 42 were reagents for anti-Trypanosoma vivax IgG antibodies, which corresponded to the prevalence of $9 \%$.

The variable purpose of exploration, related to the properties, was associated with the occurrence of trypanosomiasis, and the milk type offered a higher risk for seropositivity, when compared to the type of harvesting. Regarding the information on the herds, the variables that contributed to the increase of seropositivity were: European breed, lactating cows and mixed breeding of goats, sheep and horses. The variables foraging the banks of dams and rivers, the presence of mechanical vectors and the acquisition of animals also contributed to the increase of seropositivity. The use of disposable needles and syringes offered less risk to trypanosomosis seropositivity (Table 1).

According to the multivariate analysis, when the HosmerLemeshow test was applied, the variables foraging of banks of dams and rivers and presence of mechanical vectors continued to influence the occurrence of the infection and persisted significantly associated $(\mathrm{p}<0.001)$ with seropositivity for T. vivax (Table 2).

\section{DISCUSSION}

Analyzing the result found, the prevalence of $9 \%$ of infected animals indicates the expansion of the disease, as evidenced by LINHARES et al. (2006), and suggests that trypanosomiasis can cover large proportions, since it is the first serological survey for the detection of T. vivax antibodies in cattle in the state of Rio Grande do Norte. Although reports of the occurrence of trypanosomiasis outbreaks in Brazil are increasing, there are few studies that estimate its prevalence, based on planned samplings. Most reports relate to isolated outbreaks, in which T. vivax acutely affects cattle, manifested by high parasitemia associated with clinical signs such as fever, anorexia, weight loss, sudden drop in milk production, abortion, and perinatal mortality. However, in the Northeast region of Brazil, the work carried out by GUERRA et al. (2013) in cattle from herds of the municipalities of the state of Pernambuco found the prevalence of $13.93 \%$ (286/2053) of seropositive animals in the indirect immunofluorescence reaction.

The diagnosis of trypanosomes in the face of epidemiological data and suggestive clinical manifestations should take into account, besides the sensitivity and specificity characteristics of the technique used, its adequacy to different stages of the disease. Thus, in the chronic phase of the disease, the direct observation techniques demonstrate low sensitivity, and the laboratory diagnosis is based on immunological methods. Serological tests are especially indicated in epidemiological surveys when there is subclinical infection in herds (EISLER et al., 1998). Among the serological tests, indirect immunofluorescence reaction is the most indicated, because the sensitivity and specificity values approximate, respectively, 85.7 and $100 \%$, thus obtaining the calculation of true prevalence of specific IgG antibodies against T. vivax (BARBIERI et al., 2016).

According to the statistical analysis, the variable related to the properties that presented association with the occurrence of trypanosomosis was the type of exploration, and the milk type offered more risk (OR: 0.246; 95\%CI 0.126-0.48) for the positivity, when compared to the cut type exploration. As can be seen in Table 1, 
this result can be attributed to the intensive system with animals of breeds of European origin and high production that the milkbased system uses, since in the present study a higher occurrence of the infection in European breeds (88.1\%) than in zebuine breeds (11.9\%). On this fact, VALENTE et al. (2012) state that cows of races of European origin, especially when under tropical climates and high production conditions, are more metabolically required and therefore more sensitive to various diseases.

In this context, the study also revealed that the lactating cow animal category was another risk factor for T. vivax infection, suggesting that it is more susceptible. It is widely accepted the existence of antagonism between milk production and the incidence of diseases (ROGERS; BANOS; SANDER-NIELSEN, 1999; ABDEL-AZIM et al., 2005). In the lactating cow's body, a series of important endocrine, metabolic and nutritional changes occurs that predispose to stress, immunodepression and disease (CASTRO et al., 2009).

The acquisition and introduction of animals in the properties from surrounding microregions with $T$. vivax outbreak history in this study was considered a risk factor for trypanosomiasis. This was also important epidemiological information observed by BATISTA et al. (2007) in outbreaks of T. vivax trypanosomiasis in cattle in the interior of Paraiba. On this occasion, it was verified that the occurrence of the outbreak coincided with the introduction of animals from farms in the herd, besides the practice of renting pastures. These authors suggest that the semi-arid Northeast, due to prolonged periods of droughts and high temperatures, that do not favor the development of vectors during most of the year, is a region of enzootic instability for trypanosomiasis. Thus, outbreaks are caused by epidemiological factors that favor the occurrence of the disease, such as the presence of an abundant population of vectors in the rainy season and the introduction of animals from sites that have an unknown health history in a herd free of the disease.

Table 2. Variables that remained in the final multivariate analysis model for $T$. vivax trypanosomiasis in cattle in the Mossoró/RN microregion, 2013.

\begin{tabular}{lccc} 
Variable & $\begin{array}{c}\text { OR } \\
\text { Adjust. }\end{array}$ & $95 \% \mathrm{Cl}$ & p-value \\
\hline $\begin{array}{l}\text { Foraging } \\
\text { near weir }\end{array}$ & 14,665 & $03.448-62.384$ & $<0.001$ \\
\hline $\begin{array}{l}\text { Presence of } \\
\text { insect vectors }\end{array}$ & 03,457 & $01.527-07.825$ & 0.003 \\
\hline
\end{tabular}

OR Adjust.: odds ratio adjusted; 95\%Cl: 95\% confidence interval.

Table 1. Results of analyses of risk factors associated or not with T. vivax infection in cattle in the Mossoró/RN microregion, 2013, with the respective odds ratio (OR), confidence interval $(\mathrm{Cl})$ and statistical significance.

\begin{tabular}{|c|c|c|c|c|c|}
\hline \multirow{2}{*}{ Variable } & \multicolumn{2}{|c|}{ T. vivax (\%) } & \multirow{2}{*}{ OR } & \multirow{2}{*}{$95 \% \mathrm{Cl}$} & \multirow{2}{*}{ p-value } \\
\hline & Positive & Negative & & & \\
\hline \multicolumn{6}{|c|}{ Purpose of exploration } \\
\hline Cut & $25(59.5)$ & 364 & 0.246 & \multirow{2}{*}{$00.126-00.483$} & \multirow{2}{*}{$<0.0010^{*}$} \\
\hline Milk & $17(40.5)$ & 061 & 1.000 & & \\
\hline \multicolumn{6}{|l|}{ Sex } \\
\hline Female & $40(95.2)$ & 370 & 2.970 & & \\
\hline Male & $02(4.8)$ & 055 & 1.000 & $00.699-12.650$ & 0.1220 \\
\hline \multicolumn{6}{|l|}{ Breed } \\
\hline European & $37(88.1)$ & 312 & 2.680 & \multirow{2}{*}{$01.028-06.990$} & \multirow{2}{*}{$0.0400^{*}$} \\
\hline Zebuine & 05 (11.9) & 113 & 1.000 & & \\
\hline \multicolumn{6}{|l|}{ Animal category } \\
\hline Dry cow & $01(2.4)$ & 015 & 1.80 & $00.152-021.240$ & 0.5352 \\
\hline Lactating cow & $36(85.7)$ & 227 & 4.28 & $000.999-018.340$ & $0.0380^{*}$ \\
\hline Steers & $03(7.1)$ & 069 & 1.17 & $000.189-007.280$ & 1.0000 \\
\hline Calves & $02(4.8)$ & 054 & 1 & & \\
\hline \multicolumn{6}{|c|}{ Foraging the banks of dams and rivers } \\
\hline Yes & $40(95.2)$ & 209 & 20.67 & \multirow{2}{*}{$004.933-086.616$} & \multirow{2}{*}{$<0.0010^{*}$} \\
\hline No & $2(4.8)$ & 216 & 1 & & \\
\hline \multicolumn{6}{|c|}{ Presence of insect vectors } \\
\hline Yes & $34(81.0)$ & 181 & 5.72 & \multirow{2}{*}{$002.590-012.672$} & \multirow{2}{*}{$<0.0010^{*}$} \\
\hline No & $8(19.0)$ & 244 & 1 & & \\
\hline \multicolumn{6}{|c|}{ Acquisition of animals } \\
\hline Yes & $37(88.1)$ & 175 & 6.21 & \multirow{2}{*}{$002.381-016.230$} & \multirow{2}{*}{$<0.0010^{*}$} \\
\hline No & $5(11.9)$ & 147 & 1 & & \\
\hline \multicolumn{6}{|c|}{ Use of disposable needles and syringes } \\
\hline Yes & $0(0.0)$ & 157 & - & & \multirow{2}{*}{$<0.0010^{*}$} \\
\hline No & $42(100)$ & 268 & 1 & & \\
\hline
\end{tabular}

*Statistical significance $(p<0.05)$. 
The use of disposable syringes proved to be a protective factor. Otherwise, the non-use of syringes in vaccination and the application of drugs may serve as an important route of transmission of T. vivax in domestic ruminants, since trypanosomiasis is a hemoparasitary disease whose wide geographic distribution has been attributed to the transmission mechanics. Thus, in addition to mechanical transmission by hematophagous dipterans of trypomastigote forms, it may still occur by iatrogenic way, through the misuse of needles contaminated with infected blood in several animals, during drug application or in vaccinations (JONES; DÁVILA 2001).

The present study evidenced the association of seropositivity to T. vivax with the presence of vector insects, such as tabanids and Stomoxys sp., which, as observed, during the period in which the serological diagnosis of trypanosomiasis was carried out, these vectors were maintained at high-density population (Table 1). Among the authors investigating trypanosomiasis in cattle caused by T. vivax in Latin America, it can be seen that the occurrence of the outbreaks coincides with the increase in the density of flocks and flies of the stables, occurring during the rainy season (OTTE; ABUABARA, 1991; SILVA et al., 1996; BATISTA et al., 2012).

The results pointed to the act of foraging of the animals on the banks of dams and rivers, influencing the occurrence of bovine trypanosomiasis. A higher frequency of seropositive animals (95.2\%) was observed in grazing animals at the banks of dams and rivers, against $4.8 \%$ of seronegatives for cattle that did not graze at the banks of dams and rivers. This may be related to the fact that in these areas the humidity and temperature conditions are especially favorable to the development of forage plants and to the proliferation of hematophagous insects vectors of the disease. Thus, it is frequently concentrated in a large number of animals for grazing, which may facilitate the interaction of vector insects with animals and provide more favorable conditions to the transmission of $T$. vivax. In the meantime, the epidemiological investigation described by OTTE; ABUABARA (1991) discloses that tabanids are capable of transmitting T. vivax when blood repayment in an animal with high parasitemia is discontinued, followed by feeding into another healthy animal for up to 10 minutes.

\section{CONCLUSION}

This is the first report of the occurrence of anti-Trypanosoma vivax antibodies in cattle in the state of Rio Grande do Norte. The variables dairy farming, breeding of European origin, lactating cow, foraging at river banks and dams, besides the presence of mechanical vectors, were considered risk factors associated with the infection. This information may clarify the epidemiological factors that determine the occurrence of T. vivax trypanosomiasis in the semi-arid region.

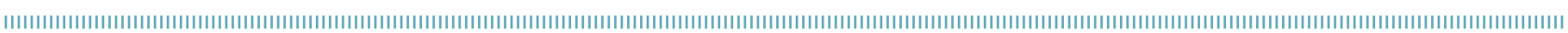
REFERENCES

ABDEL-AZIM, G.A.; FREEMAN, A.E.; KEHRLI JR, M.E.; KELM, S.C.; BURTON, J.L.; KUCK, A.L.; SCHNELL, S. Genetic Basis and Risk Factors for Infectious and Noninfectious Diseases in US Holsteins. I. Estimation of Genetic Parameters for Single Diseases and General Health. Journal of Dairy Science, Champaign, v.88, n.3, p. 1 1991207, 2005. Available from: <http://www.journalofdairyscience. org/article/SOO22-0302\%2805\%2972786-7/references>. Accessed on: Oct. 5, 2015.

ADAMS, E.R.; HAMILTON, P.B.; RODRIGUES, A.C.; MALELE, I.I.; DELESPAUX, V.; TEIXEIRA, M.M.; GIBSON, W. New Trypanosoma (Duttonella) vivax genotypes from tsetse flies in East Africa. Parasitology, Cambridge, v. 137, n.4, p.641650, 2010. Available from: <https://www.ncbi.nlm.nih.gov/ pubmed/19961657>. Accessed on: Sept. 12, 2017.

BARBIERI, J.M.; BLANCO, Y.A.C.; BRUHN, F.R.P.; GUIMARÃES, A.M. Seroprevalence of Trypanosoma vivax, Anaplasma marginale, and Babesia bovis in dairy cattle. Ciência Animal Brasileira, Goiânia, v. 17, n.4, p.564-573, 2016. Available from: <http://dx.doi.org/10.1590/10896891v17i434091 >. Accessed on: Sept. 12, 2017.

BATISTA, J.S.; BEZERRA, F.S.B.; LIRA, R.A.; CARVALHO, J.R.G.; ROSADO NETO, A.M.; PETRI, A.A.; TEIXEIRA, M.M.G. Aspectos clínicos, epidemiológicos e patológicos da infecção natural em bovinos por
Trypanosoma vivax na Paraíba. Pesquisa Veterinária Brasileira, Rio de Janeiro, v.28, n. 1, p.63-69, 2008. Available from: <http://www.scielo. br/scielo.php?pid=S0100-736X2008000100010\&script $=$ sci_ arttext>. Accessed on: Mar. 10, 2015.

BATISTA, J.S.; RIET-CORREA, F.; TEIXEIRA, M.M.G.; MADRUGA, C.R.; SIMÕES, S.D.V.; MAIA, T.F. Trypanosomiasis by Trypanosoma vivax in cattle in the Brazilian semiarid: description of an outbreak and lesions in the nervous system. Veterinary Parasitology, Ireland, v.143, n.2, p.174-181, 2007. Available from: <http://www.sciencedirect.com/science/article/pii/ S0304401706004845\#>. Accessed on: Mar. 10, 2015.

BATISTA, J.S.; RODRIGUES, C.M.F.; GARCÍA, H.A.; BEZERRA, F.S.B.; OLINDA, R.G.; TEIXEIRA, M.M.G.; SOTO-BLANCO, B. Association of Trypanosoma vivax in extracellular sites with central nervous system lesions and changes in cerebrospinal fluid in experimentally infected goats. Veterinary Research, Londres, v.42, p.63-69, 2011 . Available from: <https://veterinaryresearch. biomedcentral.com/track/pdf/10.1 186/1297-9716-4263 ? site =veterinaryresearch.biomedcentral.com $>$. Accessed on: Sept. 5, 2017.

BATISTA, J.S.; RODRIGUES, C.M.F.; OLINDA, R.G.; SILVA, T.M.F.; VALE, R.G.; CÂMARA, A.C.L.; REBOUÇAS, R.E.S.; BEZERRA, F.S.B.; 
GARCÍA, H.A.; TEIXEIRA, M.M. Highly debilitating natural Trypanosoma vivax infections in Brazilian calves: epidemiology, pathology, and probable transplacental transmission. Parasitology Research, Asia, v.110, n.1, p.73-80, 2012. Available from: <http://www.ncbi. nlm.nih.gov/pubmed/21626156>. Accessed on: Oct. 20, 2015.

BITTAR, J.F.F.; BASSI, P.B.; MOURA, D.M.; GARCIA, G.C.; MARTINSFILHO, O.A.; VASCONCELOS, A.B.; COSTA-SILVA, M.F.; BARBOSA, C.P.; ARAÚJO, M.S.S.; BITTAR, E.R. Evaluation of parameters related to libido and semen quality in zebu bulls naturally infected with Trypanosoma vivax. BMC Veterinary Research, Londres, v.11, p.261-268, 2015. Available from: <https://bmcvetres. biomedcentral.com/articles/10.1186/s12917-015-0571-x>. Accessed on: Sept. 5, 2017.

CARMO FILHO, F.; ESPINOLA SOBRINHO, J.; AMORIM, A.P. (Eds.). Dados meteorológicos de Mossoró (janeiro de 1898 a dezembro de 1986). Mossoró: ESAM/FGD, 1987. 325p.

CASTRO, D.; RIBEIRO, C.; SIMÕES, J. Medicina da produção: incidência e distribuição de doenças metabólicas em explorações de bovinos de elevada produção leiteira na Região de Aveiro, Portugal. Pubvet, Londrina, v.3, n.2, p.1-14, 2009. Available from: <http://www.veterinaria.com.pt/media/DIR_174423/ Simoes487.pdf>. Accessed on: Oct. 20, 2015.

DESQUESNES, M. Livestock Trypanosomoses and Their Vectors in Latin America. Paris: Oie \& Cirad, 2004. 174p.

EISLER, M.C.; LESSARD, P.; MASAKE, R.A.; MOLOO, S.K.; PEREGRINE, A.S. Sensitivity and specificity of antigen-capture ELISAs for diagnosis of Trypanosoma congolense and Trypanosoma vivax infections in cattle. Veterinary Parasitology, Ireland, v.79, n.3, p.187-201, 1998. Available from: <http://www.sciencedirect. com/science/article/pii/SO304401798001733?via\%3Dihub>. Accessed on: Aug. 25, 2017.

GALIZA, G.J.N.; GARCIA, A.H.; ASSIS, A.C.; OLIVEIRA, D.M.; PIMENTEL, L.A.; DANTAS, A.F.M.; SIMÕES, S.V.D.; TEXEIRA, M.M.G.; RIET-CORREA, F. High mortality and lesions of the central nervous system in Trypanosomosis by Trypanosoma vivax in Brazilian hair sheep. Veterinary Parasitology, Kentucky, v.182, n.2-4, p.359363, 2011 . Available from: <http://www.sciencedirect.com/ science/article/pii/SO304401711003542?via\%3Dihub>. Accessed on: Aug. 25, 2017.

GUERRA, N.R.; MONTEIRO, M.F.M.; SANDES, H.M.M.; CRUZ, N.L.N.; RAMOS, C.A.N.; SANTANA, V.L.A.; SOUZA, M.M.A.; ALVES, L.C. Detecção de anticorpos IgG anti-Trypanosoma vivax em bovinos através do teste de Imunofluorescência indireta. Pesquisa Veterinária Brasileira, Rio de Janeiro, v.33, n.12, p.1423-1426, 2013. Available from: <http://www.pvb. com.br/?link=verart\&tipo $=$ ID\&campo $1=1314>$. Accessed on: Mar. 20, 2015.

INSTITUTO BRASILEIRO DE GEOGRAFIA E ESTATÍSTICA (IBGE). Produção da Pecuária Municipal. Rio de Janeiro: Instituto Brasileiro de Geografia e Estatística, 2012. 71 p.
JONES, T.W.; DÁVILA, A.M.R. Trypanosoma vivax out of Africa. Trends in Parasitology, Maryland Heights, v. 17, n.2, p.99-101, 2001. Available from: <http://www.fao.org/docs/eims/upload/agrotech/1964/ r7 162_jones_davila.pdf>. Accessed on: Jan. 20, 2016.

LINHARES, G.F.C.; DIAS FILHO, F.C.; FERNANDES, P.R.; DUARTE, S.C. Tripanossomíase em bovinos no município de Formoso do Araguaia, Tocantins (relato de caso). Ciência Animal Brasileira, Goiás, v.7, n.4, p.455-460, 2006. Available from: <http://www. revistas.ufg.br/index.php/vet/article/view/876>. Accessed on: Jan. 20, 2016.

OTTE, M.J.; ABUABARA, J.Y. Transmission of South American Trypanosoma vivax by the neotropical horsefly Tabanus nebulosus. Acta Tropica, v.49, n.1, p.73-76, 1991. Available from: <http://www. sciencedirect.com/science/article/pii/0001706X9190033G\#>. Accessed on: Jan. 1, 2016.

RODRIGUES, C.M.F.; OLINDA, R.G.; SILVA, T.M.F.; VALE, R.G.; SILVA, A.E.; LIMA, G.L.; GARCIA, H.A.; TEIXEIRA, M.M.G.; BATISTA, J.S. Follicular degeneration in the ovaries of goats experimentally infected with Trypanosoma vivax from the Brazilian semi-arid region. Veterinary Parasitology, Kentucky, v.191, n.1-2, p.146153, 2013. Available from: <http://www.sciencedirect.com/ science/article/pii/SO304401712004141?via\%3Dihub>. Accessed on: Sept. 8, 2017.

ROGERS, G.W.; BANOS, G.; SANDER-NIELSEN, U. Genetic correlation among protein yield, productive life and traits from the United States and diseases other than mastitis from Denmark and Sweden. Journal of Dairy Science, Champaign, v.82, n.6, p.13311338, 1999. Available from: <http://www.sciencedirect.com/ science/article/pii/SO022030299753579>. Accessed on: Dec. 8, 2016.

SILVA, R.A.M.S.; SEIDL, A.; RAMIREZ, L.; DÁVILA, A.M.R. Trypanosoma evansi e Trypanosoma vivax: biologia, diagnóstico e controle. Corumbá: Embrapa Pantanal, 2002. $141 \mathrm{p}$.

SILVA, R.A.M.S.; SILVA, J.A.; SCHNEIDER, R.C.; FREITAS, J.; MESQUITA, D.; MESQUITA, T.; RAMIREZ, L.; DÁVILA, A.M.R.; PEREIRA, M.E.B. Outbreak of trypanosomiasis due to Trypanosoma vivax (Ziemann, 1905) in bovine of the Pantanal, Brasil. Memórias do Instituto Oswaldo Cruz, Rio de Janeiro, v.91, n.5, p.561562, 1996. Available from: <http://www.scielo.br/scielo. php?script=sci_arttext\&pid=S0074-02761996000500005 > . Accessed on: Dec. 8, 2016.

THRUSFIELD, M.V. Epidemiologia Veterinária. $2^{\text {a }}$ ed. São Paulo: Roca, 2004. 556p.

VALENTE, L.C.M.; SOUZA, E.C.; VALE, S.M.L.R.; BRAGA, M.J. Relação entre gastos preventivos e com tratamento: levantamento da situação em fazendas produtoras de leite de Minas Gerais, Brasil. Revista Brasileira de Zootecnia, Viçosa, v.41, n. 1, p.212220, 2012. Available from: <http://www.scielo.br/pdf/rbz/ v41n1/30.pdf>. Accessed on: Dec. 8, 2016. 